\title{
MANAGING THE UNMANAGEABLE? UNDERSTANDING EUROPE'S RESPONSE TO THE MIGRATION 'CRISIS'
}

\section{Heaven Crawley}

Centre for Trust, Peace and Social Relations (CTPSR), Coventry University

\section{Abstract}

More than 1 million people have crossed the Mediterranean and Aegean Seas since January 2015, arriving on the beaches of Southern Europe in dinghies and rickety boats, having paid a smuggler to facilitate their journey. Most are refugees from Syria, Afghanistan, Iraq, Eritrea, and Somalia who are fleeing conflict and violence. Others are migrants from West and Central Africa, seeking a livelihood and a future for themselves and their families. This paper will unpack the evolution of the European policy response, arguing that the migration 'crisis' is not a reflection of numbers - which pale into insignificance relative to the number of refugees in other countries outside Europe or to those moving in and out of Europe on tourist, student and work visas - but rather a crisis of political solidarity. After five emergency summits to agree a common response, EU politicians are still struggling to come to terms with the dynamics of migration to Europe, the complexity of motivations driving people forward, the role of different institutions, including governments, international organizations, NGOs and civil society, in facilitating the journey, and the ways in which social media is providing individuals and families with information about the options and possibilities that are, or are not, available to them. I suggest that the unwillingness of politicians and policymakers to engage with research evidence on the dynamics of migration and to harness their combined resources to address the consequences of conflict and underdevelopment elsewhere, speaks more strongly to the current state of the European Union than it does to the realities of contemporary migration.

Keywords: Europe, refugees, migration, geopolitics, policy, evidence

La gestión de lo ingestionable? La comprensión de la respuesta de Europa a la 'crisis' migratoria

\section{Resumen}

Más de un millón de personas han cruzado los mares Mediterráneo y Egeo desde enero de 2015, llegando en las playas del sur de Europa en botes y en embarcaciones desvencijadas, después de haber pagado a un traficante para facilitar su viaje. La mayoría son refugiados de Siria, Afganistán, Irak, Eritrea y Somalia que huyen de los conflictos y la violencia. Otros son migrantes de África Occidental y Central, en busca de un medio de vida y un futuro para ellos y sus familias. En este artículo se analiza la evolución de la respuesta de la política europea, con el argumento de que la "crisis" de migración no es un reflejo de los números los cuales son insignificantes en relación al número de refugiados en otros países fuera de Europa o a los que se mueven dentro y fuera de Europa con visas de turista, 
estudiante y trabajo - sino más bien de una crisis de solidaridad política. Después de cinco cumbres de emergencia para acordar una respuesta común, los políticos de la UE todavía están luchando para llegar a un acuerdo con la dinámica de la migración a Europa, la complejidad de las motivaciones llevando a la gente hacia adelante, el papel de las diferentes instituciones, incluidos los gobiernos, organizaciones internacionales, organizaciones no gubernamentales, y la sociedad civil para facilitar el viaje y las formas en que las redes sociales están proporcionando a las personas y familias con información acerca de las opciones y posibilidades que están, o no están, a su disposición. Sugiero que la falta de voluntad de los políticos a comprometerse con los datos de investigación sobre la dinámica de la migración y de aprovechar sus recursos en conjunto para enfrentar a las consecuencias de los conflictos y el subdesarrollo en otros lugares, refleja más sobre la situación actual de la Unión Europea que sobre las realidades de la migración contemporánea.

Palabras clave: Europa, refugiados, migración, geopolítica, política, evidencia

\section{Introduction}

According to the International Organization for Migration, more than one million people made the dangerous journey across the Mediterranean and Aegean Seas in 2015 looking for a new life in the countries of Europe (IOM 2016). A further 3,770 people were recorded as dead or missing, although the actual figure is almost certainly higher. Images of desperate men, women and children moving into and across Europe filled our newspapers and TV screens and dominated political and policy debates for much of the year. This trend has continued into 2016: in the first six weeks of the year, more than 90,000 people arrived in Greece and Italy by sea, with a further 411 recorded as dead or missing. ${ }^{1}$ Most are refugees from Syria, Afghanistan, Iraq, Eritrea, and Somalia, fleeing conflict and violence. Other sea-borne arrivals are

1 IOM's Missing Migrants Project tracks the deaths of migrants and those who have gone missing along migratory routes worldwide based on statistical data from governments, and sources other agencies, as well as NGOs and the media (http:// missingmigrants.iom.int/mediterranean). migrants from West and Central Africa, looking to earn a livelihood and to make a future for themselves and their families.

This paper unpacks the European policy response to this movement of people, arguing that the migration 'crisis' is not a reflection of numbers per se but rather that it is symptomatic of a wider geopolitical crisis which reflects profound and longstanding differences between EU member-states and across the wider European region. It will be suggested that the unwillingness and seeming inability of politicians and policymakers to engage with an extensive body of evidence on the dynamics of migration and to harness their combined political and economic resources to address the consequences of conflict and economic underdevelopment elsewhere, reveals more about the current state of the European Union, established as a peace project to build political consensus in the aftermath of World War Two, than it does about the realities of contemporary migration.

\section{Understanding the drivers of migration to Europe}

Whilst the scale of recent population movements should not be underestimated, this is not the first time that hundreds of thousands of people have been on the move in Europe looking for a better life for themselves and their children. Many of today's scenes are reminiscent of the last major period of unrest in Europe when conflict ripped apart the former Yugoslavia in the 1990s, leading not only to the creation of more than half a dozen new countries in the Western Balkans but also to the displacement of huge numbers of people, including 1.2 million Bosnian refugees. Fifty years earlier, the Second World War created an estimated 60 million refugees - migration on a significantly larger scale than the refugee flows in Europe today. This mass movement of people did not stop with the end of the war but continued as Europe reorganized itself to accommodate the new political structures established in its wake.

The current crisis has historical precedents but should also be understood in a global context. Research funded by the European Commission more than a 
decade ago found that the majority of those seeking asylum in the EU during the 1990s came from just ten countries in which there was well-documented conflict, persecution and human rights abuse (Castles et al. 2003). These trends have accelerated in the twenty-first century. According to the UNHCR (the UN's agency for refugees), wars, conflict and persecution have forced more people to flee their homes than at any other time since records began: the number of people forcibly displaced at the end of 2014 had risen to a staggering 60 million compared to just over 50 million a year earlier and 37.5 million a decade before that (UNHCR 2015a). Fighting across parts of the Middle East and sub-Saharan Africa continued through 2015, resulting in millions of individuals being forced to flee, either within or outside their country (UNHCR 2015b). No surprise, then, that, of those who crossed the Aegean in 2015, 50 per cent were from Syria, 20 per cent from Afghanistan, 7 per cent from Iraq, 4 per cent from Eritrea, 2 per cent from Iran and 1.6 per cent from Somalia (IOM 2016). Indeed around 90 per cent of those arriving across the Mediterranean and Aegean Seas in 2015 originated from the world's top ten refugee-producing countries. $^{2}$

The answer to the significant increase in irregular migration to Europe over recent years lies, in large part therefore, with the conflict in Syria, which began in March 2011 but has escalated over the past five years, drawing in countries within and outside the region and closely associated with the rise of the Islamic State of Iraq and Syria (ISIS). More than 12 million Syrians have been forced to leave their homes and Syria is now the largest source country of refugees, with a refugee population of 4.2 million by mid-2015, replacing Afghanistan as the main source of refugees worldwide, a position that the latter country was unfortunate enough to hold for more than three decades (UNHCR 2015a). Many of these people live in refugee camps in Jordan and Lebanon or in urban settings within Turkey. The numbers of refugees in these countries far exceed those in the countries of Europe, particularly given the size and relative poverty of the existing population: for example, around 1.5 million refugees are

2 See http://data.unhcr.or/mediterranean/country.php?id=83 for the latest data on their nationalities. currently living in Lebanon, a country half the size of Wales (UNHCR 2015b). Estimates from those on the ground put the number closer to 2 million. Serious underfunding of efforts to host Syrian refugees in the region has meant that many have moved on in an attempt to find a place where they can rebuild their lives (Spijkerboer 2016).

However, Syria is not the only country in which there is conflict and human rights abuse. In the past five years, at least 15 conflicts have erupted or reignited, eight in Africa (Côte d'Ivoire, Central African Republic, Libya, Mali, North-Eastern Nigeria, the Democratic Republic of Congo, South Sudan and Burundi), three in the Middle East (Iraq, Yemen and Syria), one in Europe (Ukraine) and three in Asia (Kyrgyzstan and several areas of Myanmar and Pakistan) (UNHCR 2015a). Aside from Syrians, most of those arriving in Greece are refugees from Afghanistan and Iraq. In Italy the countries from which people travel are more diverse - Eritrea, Nigeria, Somalia, Gambia, Mali and Senegal - but the conditions that they leave behind are equally difficult. Human Rights Watch has recently described the situation in Eritrea as 'dismal' (see www.hrw.org/africa/eritrea). In Nigeria the militant insurgent group Boko Haram has killed civilians, abducted women and girls, forcefully conscripted young men and boys, and destroyed homes and schools, displacing hundreds of thousands of people.

It is important to acknowledge that there are also significant numbers of people for whom migration to Europe forms part of a livelihood strategy in the context of poverty, underdevelopment and a lack of opportunity. The irregular movement of people seeking work should also be viewed in a wider European and, indeed, global context. For many millions of people, migration for work is an everyday part of life: there are an estimated 232 million international and 740 million internal migrants in the world (IOM 2015). The dynamics of labor migration vary regionally but in the European context it is clear that substantial shifts in the skill levels of some parts of the European Union, combined with an overall ageing population, is driving demand for both high- and low-skilled labor. All the signs suggest that the population of the EU will 
fall by around 50 million people in the next 35 years and with it the number of people in the active labor force (Merritt 2015). This shrinkage of the workforce will have significant implications for the balance between tax receipts and social welfare expenditure, not least because the ageing population will also lead to higher costs for pension and social-care provision. To date the political leaders of the EU have largely refused to acknowledge this gap, arguing that lowskilled migration from outside Europe drives down wage rates and creates additional pressure on health, education and welfare systems. As a result it is difficult, if not impossible, for workers from outside Europe to secure the right to work legally. Instead they have joined the ranks of refugees unable to secure access to international protection without first entering the territory, creating an unprecedented demand for the services of the agents, smugglers and traffickers who facilitate the complex and increasingly dangerous journey to Europe (Andersson 2014; Collyer 2015).

\section{Mind the (very big) gaps}

In terms of recent migration flows and trends, the so-called migration 'crisis' was utterly predictable (Spijkerboer 2016). Events associated with the Arab Spring in late 2010, the ousting of Libya's Muammar Gaddafi the following year and, of course, the Syrian civil war meant that the exodus of millions of people from the region was almost inevitable. In the longer term, shifting patterns of work and leisure associated with globalization and increased communications have revolutionized knowledge and perceptions of other parts of the world and accelerated access to information about how, and where, to travel (Collyer 2015; Thulin and Vilhelmson 2015). European politicians and policymakers should not have been surprised when people started to arrive through irregular means in much larger numbers than previously and yet they were. Why? Because they chose to ignore all the evidence, seemingly fixated on short-term objectives and oblivious to the fact that, by generating, or pandering to, anti-immigrant sentiment, they have limited the options for doing things differently.

The (non)response of Europe's political leaders to increased migration highlights a number of (very big) gaps in migration policy and practice. The first of these - which is evident at both national and supra-national levels - is the development of policies which are out-of-sync with and therefore unable to respond appropriately to the complex and rapidly changing dynamics of international migration. This is despite a plethora of in-depth research studies which provide detailed empirical evidence on the reasons why people move, the factors shaping decision-making at the individual and group levels, the importance of social relationships and networks, and the role of agents and others who facilitate the journey in the context of increased border controls (Andersson 2014; Collyer and de Haas 2012; Crawley 2010; Cummings et al. 2016; Düvell 2012). This gap is reflected in the dominance of certain assumptions about the dynamics of international migration, one of which is the idea that people depart from their country of origin with a clear and fixed idea of the country in which they will arrive, their 'final destination'. Collyer (2015), among others, has found no evidence to support the idea that large numbers of people are leaving their countries of origin with the intention of reaching Europe. Rather, for those leaving Ethiopia, Sudan and Egypt, the idea of crossing the Mediterranean often arose from disappointment at the conditions in the neighboring countries.

Assumptions about the linearity of migration are reflected in ideas about the relationship between so-called 'push' and 'pull' factors and in policies that are directed towards 'tipping the balance' between the two, most often by removing rights and access to resources in destination countries. Geographers and others have long been critical of simplistic, linear accounts of international migration which are underpinned by assumptions about the relationship between these so-called 'push' and 'pull' factors. These criticisms have increased as migrants' journeys have become longer and more fragmented in response to new spatialities of migration control which are continually reconfigured in an effort to reduce or eliminate irregular movement (Collyer 2015). In the context of European migration policy, this conceptualization of the 'tipping point' between the two presupposes that people on the move know and understand the nuances of migration policy and practice across a 
wide range of European member-states and that they understand the implications of often rapidly changing policies for their particular individual and/or family circumstances. In reality those who move often lack this information and the decision about where to go is more often based on a whole range of intervening variables and opportunities that arise on the journey (Collyer and de Haas 2012) or via those who facilitate it (Andersson 2014; Collyer 2015; Crawley 2010). Existing empirical studies suggest that, whilst some policies may significantly affect the targeted migration flows, migrant decision-making is also influenced by a number of other determinants, including factors relating to economic growth, labor market structure, education, inequality, and conflict (Czaika and de Haas 2013). The impact of individual policies is thus dependent upon a range of other variables over which migration policymakers may have limited control. A similar point is made by Castles (2004: 223), who argues that the forces driving international migration are not only complex but also deeply embedded in general processes of social transformation:

It is important to understand much of contemporary migration (and particularly those flows seen by some as constituting a 'migration crisis') as an integral aspect of North-South relations in the current phase of globalisation. Policy in this area is doomed to failure unless it addresses the causes of both economic and forced migration [as being rooted in] patterns of global inequality.

This brings us to the final assumption underpinning European policy: that it is possible to differentiate easily between those who can be categorized as 'refugees' and those who are 'economic migrants'. Within academia it is widely accepted that a continuum is a more accurate representation than a dichotomy, not least because causes and motivations are individual as well as mixed and often changing (Collyer and de Haas 2012). Categories established to help policymakers, decision-makers and academics to make sense of movement are not necessarily a good reflection of what is actually going on (Bakewell 2008). They may, in fact, serve to make more difficult the task of policy delivery, especially where other sets of policies (in this case relating to entry into the EU) push people to travel irregularly in 'mixed flows' with others who, themselves, have multiple migration motives, many of which may have changed over the course of their journey (see also Collyer 2015; Crawley 2010; Düvell 2012). Nonetheless, assumptions about categories pervade the European response to the migration 'crisis', in turn creating one of its own namely the difficulty of processing large numbers of irregular arrivals in some of Europe's poorest and most under-resourced countries.

The insistence of politicians and policymakers to ignore the growing body of evidence on the dynamics of international migration goes some way towards explaining why the policies that have been put in place in an effort to respond to the migration 'crisis' have failed to deliver what was promised or expected. But this is only part of the story. Just as importantly, there has been a spectacular level of non-implementation in relation to those policies which have been agreed. Five emergency migration summits to 'solve' Europe's crisis have done little other than to demonstrate that it is incapable of doing so, in turn creating an unprecedented political crisis that threatens to undermine the foundations of the Union itself. ${ }^{3}$

Most striking in this regard has been the failure of European member-states to deliver on a scheme to relocate 160,000 of those arriving in Greece and Italy, the countries in which arrivals have been highest due to their geographical proximity to the Middle East and North Africa respectively, to other countries in which arrivals have been very much lower. As of 4 February 2016, just 481 people had been relocated, 279 (out of an agreed 39,600) from Italy and 202 (out of an agreed 66,400) from Greece. ${ }^{4}$

Several member-states, including the UK, Ireland, Denmark and Hungary, have simply refused to participate in the scheme, citing a number of reasons which range from the assumed 'pull factor of relocation' to

3 See www.euractiv.com/section/justice-home-affairs/news/ tusk-calls-migration-summit-number- $5 /$.

4 See http://ec.europa.eu/dgs/home-affairs/what-we-do/policies/european-agenda-migration/press-material/docs/state_of_ play___relocation_en.pdf. 
the difficulties of integrating Muslims. Others have agreed to participate but have offered limited places, blaming the delays on a series of factors: the need to increase security checks in the wake of the Paris and Brussels attacks, a lack of housing and education for asylum-seekers, and logistical problems over chartering planes. The scheme's failure thus far means that many migrants no longer believe that they will be moved from Greece or Italy and, instead, are making their own way to preferred destinations like Germany and Sweden.

The consequences of the EU's failure to deliver on its promises and to share responsibility for dealing with the migration 'crisis' are significant and potentially far-reaching. Firstly, it has undermined confidence in the ability of the EU to deliver political and policy solutions, in turn creating a political crisis the consequences of which are as yet unknown. Secondly, it has shifted the focus decisively onto migration as 'the problem'. The process of cascading border closures within Europe continues apace but has been supplemented by an increased emphasis on securing Europe's external border and on preventing refugees and migrants from arriving in Europe in the first place. At the end of 2015, the EU agreed to give Turkey $€ 3$ billion in return for the country's co-operation in limiting the number of people arriving in Europe through Greece. Then, at the end of January 2016, the EU threatened to expel Greece from the Schengen area, ${ }^{5}$ a political manœuver aimed at putting pressure on the Greek government to tighten the country's border with Turkey. Greece's potential expulsion does not offer any solution to the migration 'crisis' or the structural and ideological problems facing the EU: it is simply an attempt to punish the Greek government for its perceived failure to control the movement of people through the country and onwards into the Western Balkans. But it provides a very interesting window into the geopolitics of Europe's response to

5 The Schengen Area is a collective of 26 European countries that have mutually decided to eliminate passport and immigration controls at their joint borders. Within it, concurrently, the citizens of these countries are free to travel in and out of this zone as one single country sharing equal international travel rights (www.schengenvisainfo.com/schengen-visa-countries-list/). migration and, in turn, why this issue has developed into a 'crisis'.

\section{The geopolitics of Europe's migration 'crisis'}

The 'migrant crisis' has revealed a topsy-turvy world of prejudices, misunderstandings and sheer political opportunism. The absence of an EU policy to cope with the flow of conflict refugees and others who are simply seeking a better life is shaming, yet at its root is a European mindset that sees immigration as a danger instead of welcoming it as an opportunity (Merritt 2015: 1).

In the absence of a willingness to engage with the dynamics of migration in Europe and in the context of a lack of solidarity, the countries of Europe have, instead, turned to blaming one another for the 'crisis'. This process of scapegoating and finger-pointing has thrown up long-standing geopolitical interests and conflicts both between member-states, and between member-states and those with aspirations to become part of the EU. The process began with Germany, which has been accused of throwing open the borders of Europe with little or no regard to the consequences for the countries of Southern Europe and the Western Balkans through which migrants and refugees need to pass in order to reach its territory. Particular venom has been directed towards Chancellor Angela Merkel, one of a limited number of female leaders in Europe, who has been accused of being 'emotional' and of trying to redeem Germany for the sins of its past, most notably, of course, World War Two - and specifically the Holocaust. Despite, or perhaps because of, its dominant economic and political role in Europe, World War Two remains a very big stick with which to beat the Germans.

But the scapegoating has not been limited to Germany. The most recent wave of hostility has been directed towards Greece, which has been accused by the EU of neglecting its obligations and displaying serious deficiencies in carrying out external border controls. ${ }^{6}$ Greece has, of course, long been regarded as

6 European Commission Press Release - Commission adopts Schengen Evaluation Report on Greece and proposes 
incompetent: just as the migration 'crisis' was starting to escalate at the beginning of Summer 2015, negotiations were under way to come up with a solution to the Greek debt crisis which had developed since late 2009 and which threatened the country's membership of the Eurozone. The crisis was largely attributed to the Greek government's economic incompetence. By the end of 2015 a beleaguered Greek state, reeling from an economic crisis and austerity measures that have led one in four of its population to be unemployed, together with political instability and two elections within a matter of months, had received 850,000 migrants and refugees arriving on its shores from the beaches of Turkey, just $10 \mathrm{~km}$ across the Aegean Sea.

It is not possible to understand why so many people have been able to make the irregular crossing from Turkey to Greece without understanding the tense geopolitics and the complex and longstanding dispute over the Aegean Sea that dominate the relationship between the two countries and which are played out on a daily basis on its waters (Heraclides 2011; Vassalotti 2011). The political geography of the region is characterized by islands in the eastern part: Chios, Lesvos, Iraklides, Rhodes, Samos, Kos and many others, which are very close to the Turkish coast but in fact are Greek territory. The boundaries were established in accordance with the Treaty of Lausanne in 1923, which recognized the dissolution of the Ottoman Empire and established Turkey's current borders. ${ }^{7}$ Both nations disagree on the sovereignty of certain Greek islands, islets and even rocks, the continental shelf delimitation and the territorial sea breadth (Vassalotti 2011). In the early 1970s, Turkey initiated a systematic policy of claims against the sovereignty, sovereign rights and international responsibilities of Greece in maritime, island and air space. The advent of this new Turkish policy coincided with the Turkish invasion of Cyprus in July 1974 and subsequent occupation of the island's northern portion, which continues to this day, decisively impacting on

recommendations to address deficiencies in external border management, 2 February 2016 (http://europa.eu/rapid/press-release_IP-16-211_en.htm).

7 At this time, Turkey lost not only the Aegean Sea islands, but also control over Arabia, Egypt, Sudan, Tripolitania, Cyrenaica, Mesopotamia, Palestine, Transjordan, Lebanon and Syria, with new states being created in these regions. relations between the two countries and increasing tensions. As is noted by Chapsos (2016), dealing with the movement of large numbers of people across the Aegean has been made all the more difficult given Greece and Turkey's refusal to work together, a mutual animosity which stems from longstanding maritime territorial disputes and threat perceptions. The arrival of NATO ships in the Aegean, ostensibly to provide information and surveillance to counter human trafficking and criminal networks rather than to push back the boats to Turkey, adds a further dimension to this already highly complex - and highly militarized political context.

At the same time there are increasing noises from European leaders that the Former Yugoslav Republic of Macedonia (FRYOM) is the only country able to save Europe from the incompetence of the Greeks. ${ }^{8}$ If efforts to persuade the Turks to prevent the arrival of large numbers of people across the Aegean fail, then the closing of the Greek-Macedonia border would effectively turn Greece into a de facto refugee camp holding hundreds of thousands of people in a context already of significant political and economic instability. This would be very bad news for Greece but rather better news for FRYOM, which is keen to accelerate its accession to the EU. Since FRYOM seceded from Yugoslavia in 1991 and declared its independence as the 'Republic of Macedonia', the Greek government has argued that this name will leave Greece open to territorial disputes between Skopje and a region of Greece also called Macedonia. In response, Athens has blocked Macedonian membership of NATO and the EU until the dispute is resolved. ${ }^{?}$

The politics of the migration 'crisis' in Europe also risks re-igniting old tensions among the Western Balkan nations, which have struggled to rebuild

8 'Junker drops Greece, bets on Macedonia', Politico, 26 January 2016 (www.politico.eu/article/juncker-drops-greece-bets-on-macedonia-eu-migration-refugees-asylum-european-union-schengen/).

9 More information about the history of the 'name issue' can be found on the website of the Hellenic Republic Minister of Foreign Affairs, which notes that the issue is a 'major point of friction between the two countries' and accuses FYROM of 'failing to respect the principle of good neighbourly relations' (www.mfa.gr/en/fyrom-name-issue/). 
relations in the period since the break-up of Yugoslavia. During the course of 2015 and into 2016, a very strong narrative has developed which identifies the Balkans as a region of transit for those arriving in Greece and traveling onwards towards Germany and Northern Europe. The use of the term 'transit migration' in this context provides a clear example of the way in which the concept has become politicized and used to exert political pressure to contain 'unwanted' migration flows (Düvell 2012). The situation is actually more complicated than this narrative might suggest. In reality there is very significant outward migration from the region, primarily by those unable to make a livelihood for themselves and their families. More than a third of all asylum-seekers arriving in Germany in 2015 came from Albania, Kosovo and Serbia. According to Koelbl et al. (2015: 1 ), outward migration from the region shows that the wounds of the Balkan wars have not yet healed:

Slovenia and Croatia are now members of the European Union, but Kosovo, which split from Serbia and became prematurely independent in 2008, carves out a pariah existence. Serbia is heavily burdened with the unresolved Kosovo question. The political system in Bosnia-Hercegovina is on the brink of collapse, 20 years after the end of the war there. And Macedonia, long the post-Yugoslavia model nation, has spent two decades in the waiting rooms of the EU and NATO, thanks to Greek pressure in response to a dispute over the country's name. The consequences are many: a lack of investment, failing social welfare systems, corruption, organized crime, high unemployment, poverty, frustration and rage.

These problems and the political divisions which mark relations between the Balkan states are, in many respects, being downplayed in the interests of securing EU membership but they have not gone away. Relations between the EU-Turkey and Russia, which have deteriorated significantly over recent months, have the potential to divide the countries of the Western Balkans still further.
In other member-states the geopolitics of Europe's migration 'crisis' have similarly been played out along existing lines of fracture and used to leverage political and public support at the national level. In the UK, the 'jungle' refugee camp at Calais has become a source of continuing irritation with France in ways that are reminiscent of the Sangatte refugee camp which opened in 1999. The issue of a potential British exit from the EU has focused on the rights of EU nationals to access in-work benefits if they take up low-paid or low-hour jobs in the UK. Anti-migrant attitudes, racism and Islamophobia, and the direct linking of migration to issues of security and threats of terrorism, have marked not only public opinion in the countries of Europe but also the rhetoric of many of its political leaders. In the summer of 2015, when the numbers of people arriving through Greece were on the rise, Hungary's prime minister, Viktor Orbán, sent a letter to every single resident of Hungary along with a questionnaire asking citizens how they thought the government should respond to Europe's migration 'crisis'. The letter opened with a warning of Charlie Hebdo-style killings in Hungary. The first question mentioned ISIS.

In this context it is absolutely clear that the 'crisis' is rather less about the issue of how to respond appropriately to the irregular arrival of migrants and refugees and rather more about the wider geopolitics of the EU and the region more generally. Much of what is said and done in response to the 'crisis' serves the purpose of positioning countries in relation to one another or of signaling to the domestic population that the government is 'standing up for' a particular country and 'protecting' its rights and interests. The findings of the Hungarian survey, answered by nearly 1 million citizens, were used to legitimate a series of giant billboards intended to send a message to migrants to stay away or move on: 'If you come to Hungary, you mustn't take away Hungarians' jobs', 'If you come to Hungary, you must respect our culture', and 'You must abide by our laws'. However, since few migrants and refugees actually understand Hungarian, these warnings were part of a larger push to increase public anxiety and win support among citizens for planned anti-immigration laws and measures. ${ }^{10}$ Only

10 A spoof Hungarian political party went on to mock the 
a few days after the first billboards were unveiled, Orbán announced that Hungary would be building a $4 \mathrm{~m}(13 \mathrm{ft})$ razor-wire fence along its $175 \mathrm{~km}(110$ mile) border with Serbia. The fence was completed on 15 September, trapping tens of thousands of migrants and refugees in Serbia, which had not been officially informed that the border would close. Around the same time, Hungary's parliament passed a law allowing the army to use rubber bullets, water cannons, tear-gas grenades and net guns against those trying to enter, triggering a wave of media reports and images in which migrants and refugees were presented as aggressive young men trying to fight their way into Europe. ${ }^{11}$ Hungary's border with Croatia was closed one month later.

\section{So can the 'crisis' be managed?}

Large-scale movements away from violent and protracted conflicts are sadly not exceptional. Neither is mixed migration a new or poorly understood phenomenon. What makes today's situation exceptional is the current geopolitical configuration of the countries of Europe combined with, and exacerbated by, public policy failings and complex (often historical) issues around the identity of member-states and the EU as a whole. The problem is that many of the policies devised in response to increased migration are directed not at responding to the movement of people and addressing their needs but, rather, at managing the fears and anxieties of politicians and the public alike, which have become unmanageable because they are based on a lack of evidence and understanding of the reasons why people are on the move, allied with misinformation, prejudice and racism.

Europe has backed itself into a political corner. By talking up the 'threat' of migration for more than a decade, it now finds itself ill-equipped to respond in any way other than lashing out - at migrants and refugees but also at fellow and emerging member-states, who

government's anti-immigrant rhetoric, suggesting that its first priority should be to encourage droves of Hungarian job-seekers who have emigrated to come home (www.pri.org/ stories/2015-07-08/hungarians-use-wit-paint-and-little-photoshop-deface-anti-immigration-billboards).

11 'Migrant crisis: clashes at Hungary-Serbia border' (www. bbc.co.uk/news/world-europe-34272765). are blamed for creating or exacerbating the problem in the first place. Many commentators have emphasized that, in order to survive the 'crisis', Europe must restore a sense of control, focused almost exclusively on the securing of Europe's external border. But if the EU's sense of control is based wholly or mainly on stopping people from entering Europe then it is in trouble. There is too much at stake for refugees and migrants, and for the industry that has grown up around them, for that to be effective (Andersson 2014). There will always be ways around the fences or across the sea: the risks to individuals and families will simply increase proportionately. Already there are numerous reports of alternative smuggling routes being created through Macedonia and Albania, as well as migrants reaching border points with forged identification papers.

In order to restore a sense of control, politicians and policymakers also need to talk about the issue of migration to Europe differently. They need to situate the irregular movement of people into its historical and geographical contexts and to acknowledge that the policies associated with the 'Fortress Europe' project over the past 25 years have run counter to the needs of Europe and have created an industry of smugglers and traffickers for whom the business opportunities are high. Most importantly they need to create a new political narrative about the rights of migrants and refugees which not only rehumanizes 'Them' but, in turn, rehumanizes ' $U s$ ' by serving as a reminder that the values of the European project, forged in the wake of the Second World War which ripped Europe apart and set communities against one another, are values that are important to us individually and as part of our collective identity.

If ever there was a time when the EU needed to take a deep breath and look at ways in which to revitalize its relationships internally and with the outside world, it is now. Seen from this perspective, the only policies that can 'manage' or at least go some way towards assuaging public and political anxiety about the migration 'crisis' are those that are prepared to tackle head-on the real causes of the 'crisis'. This means acknowledging that Europe needs migration, talking explicitly about the rights of refugees to seek international protection and the ability of the EU to provide 
it, increasing resettlement on a very significant scale for those for whom there are no immediate prospects of local integration or return, opening up legal routes for those who are looking for work (but requiring regulation of the labor market and their access to it to protect migrants and low-paid workers) and tackling head-on the racism and xenophobia that has become normalized not only in many sections of the media and the right-wing groups springing up across Europe but also more generally in public and political debate within member-states. It also means acknowledging Europe's failure to deliver social and economic equality for its populations, standing up for the rights of those who have least power, who are marginalized and discriminated against on a daily basis, and being consistent in relation to those policies which impact directly upon populations living outside Europe trade, investment, the sale of arms and weapons. Only then will the 'crisis' associated with the movement of people into Europe become one that is manageable.

\section{References}

All online references last accessed 19 February 2016.

Andersson, R. (2014) Illegality, Inc: Clandestine Migration and the Business of Bordering Europe. Berkeley: University of California Press.

Bakewell, O. (2008) 'Research beyond the categories: the importance of policy irrelevant research into forced migration', Journal of Refugee Studies, 21(4): 432-453.

Castles, S. (2004) 'Why migration policies fail', Ethnic and Racial Studies, 27(2): 205-227.

Castles, S., Crawley, H. and Loughna, S. (2003) States of Conflict: Causes and Patterns of Forced Migration to the EU and Policy Responses. London: IPPR, available at www.ippr.org/publications/statesof-conflict-causes-and-patterns-of-forced-migrationto-the-eu-and-policy-responses.

Chapsos, I. (2016) 'What are NATO's ships in the Aegean really keeping an eye on?', The Conversa- tion, 16 February, available at https://theconversation. com/who-are-natos-ships-in-the-aegean-really-keeping-an-eye-on-54665.

Collyer, M. (2015) Conditions and Risks of Mixed Migration in North East Africa. MHub (North Africa Mixed Migration Task Force), available at www.mixedmigrationhub.org/resources/mmtf-noah-research.

Collyer, M. and de Haas, H. (2012) 'Developing dynamic categorisations of transit migration', Population, Space and Place, 18(4): 468-481.

Crawley, H. (2010) Chance or Choice? Understanding Why Asylum Seekers Come to the UK. London: Refugee Council, www.refugeecouncil.org.uk/ assets/0001/5702/rcchance.pdf.

Czaika, M. and de Haas, H. (2013) 'The effectiveness of immigration policies', Population and Development Review, 39(3): 487-508.

Cummings, C., Pacitto, J., Lauro, D. and Foresti, M. (2016) Why People Move: Understanding the Drivers and Trends of Migration to Europe. London: Overseas Development Institute (ODI), www.odi.org/ sites/odi.org.uk/files/odi-assets/publications-opinion-files/10208.pdf.

Düvell, F. (2012) 'Transit migration: a blurred and politicised concept', Population, Place and Space, 18(4): 415-427.

Heraclides, A. (2011) The Essence of the GreekTurkish Rivalry: National Narrative and Identity. Athens: Hellenic Observatory European Institute, GreeSE Paper No. 51, available at http://eprints.lse. ac.uk/45693/1/GreeSE\%20No51.pdf.

IOM (2015) World Migration Report 2015. Geneva: International Organization for Migration, www.iom.int/world-migration-report-2015.

IOM (2016) Mixed Migration: Flows in the Mediterranean and Beyond: Compilation of Available Data and Information 2015. Geneva: International Organization for Migration (GMDAC), available at 
http://doe.iom.int/docs/Flows\%20Compilation\%20 2015\%20Overview.pdf.

Koebl, S., Kuntz, K. and Mayr, W. (2015) 'Mass migration: what is driving the Balkan exodus?', Spiegel Online, 26 August, http://www.spiegel.de/international/europe/western-balkan-exodus-puts-pressureon-germany-and-eu-a-1049274.html.

Merritt, G. (2015) 'The refugee crisis: Europe needs more migrants, not fewer,' Friends of Europe, Future Europe, 20 October. www.friendsofeurope.org/ future-europe/the-refugee-crisis-europe-needs-moremigrants-not-fewer/.

Spijkerboer, T. (2016) 'Europe's refugee crisis: a perfect storm', www.law.ox.ac.uk/research-subject-groups/centre-criminology/centreborder-criminologies/blog/2016/02/europe's-refugee.
Thulin, E. and Vilhelmson, B. (2015) 'The internet and desire to move: the role of virtual practices in the inspiration phase of migration', Tijdschrift voor Economische en Sociale Geografie, Early view DOI: 10.1111/ tesg. 12144 .

UNHCR (2015a) World At War - UNHCR Global Trends: Forced Displacement in 2014. Geneva: http:// unhcr.org/556725e69.html.

UNHCR (2015b) Mid Year Trends 2015. Geneva: www.unhcr.org/56701b969.html.

Vassalotti, J. (2011) 'Rough seas: the GreekTurkish Aegean Sea dispute and ideas for resolution', Loyola of Los Angeles International and Comparative Law Review, 33(3): 387-399, available at http:// digitalcommons.lmu.edu/ilr/vol33/iss3/2.

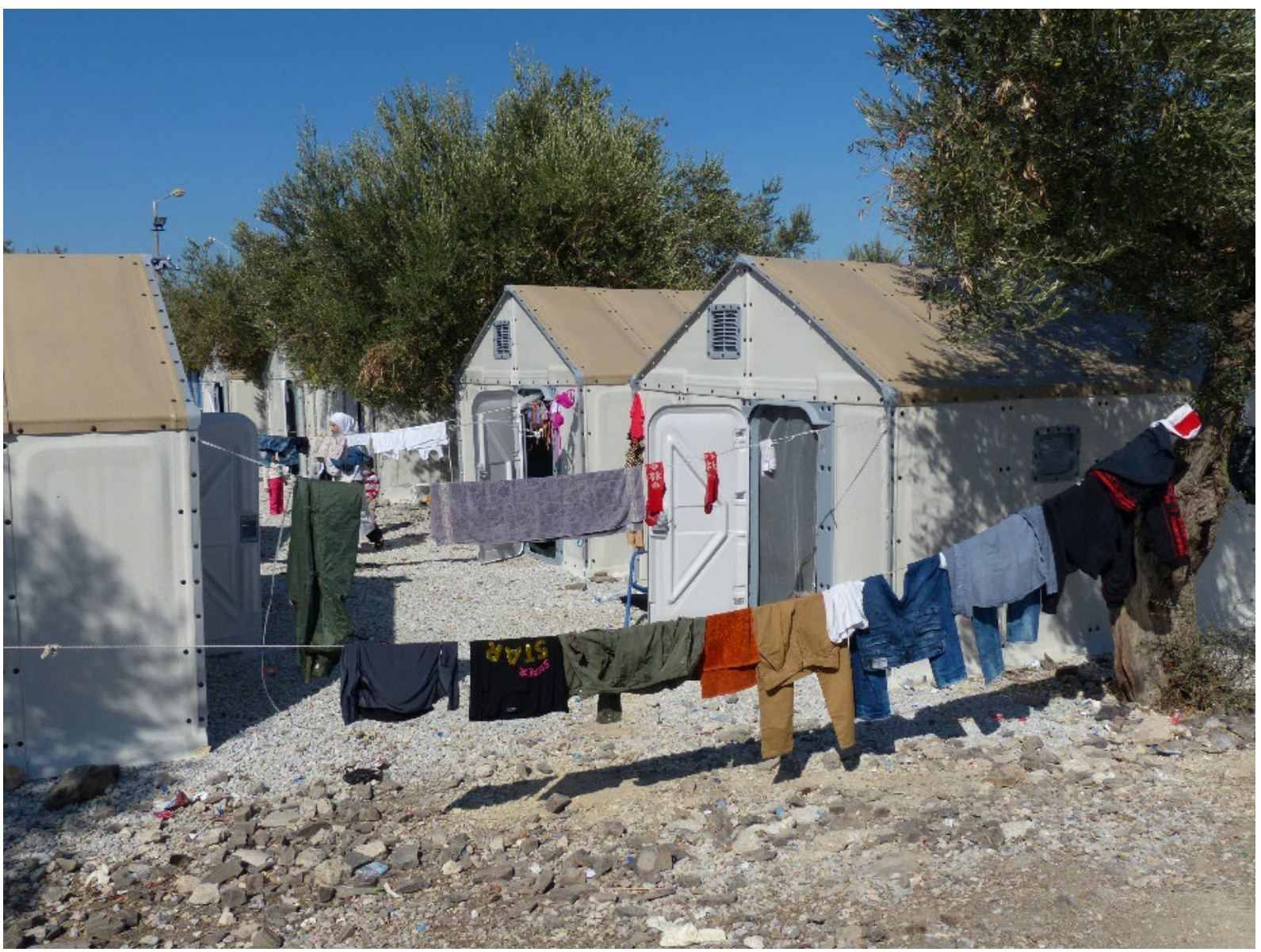

